Article

\title{
Incident Light and Leaf Age Influence Leaflet Element Concentrations of Cycas micronesica Trees
}

\author{
Thomas E. Marler $1, *$ (1) and Murukesan V. Krishnapillai ${ }^{2}$ \\ 1 College of Natural and Applied Sciences, University of Guam, Mangilao, GU 96923, USA \\ 2 Cooperative Research and Extension, College of Micronesia-FSM, Yap Campus, Kolonia 96943, Federated \\ States of Micronesia \\ * Correspondence: marlert@triton.uog.edu; Tel.: +16-7-1735-2100
}

Received: 21 June 2019; Accepted: 2 August 2019; Published: 7 August 2019

\begin{abstract}
The need for improved knowledge on conservation and management of cycad species has generated recent interest in compiling a database on leaf nutrient concentrations. However, the sampling protocols have not been consistent among reports and the influences of some plant and habitat traits on the plasticity of cycad leaf nutrient concentrations has not been adequately determined. We used Cycas micronesica K.D. Hill trees to determine the role of incident light level and leaf age on leaflet content of 11 essential elements. Shade leaves exhibited increased mass-based concentration for nitrogen, phosphorus, and potassium above that of sun leaves. Shade leaves exhibited decreased area-based concentration for all of the macro- and micronutrients below that of sun leaves. Mass-based concentration of nitrogen, phosphorus, and potassium decreased with leaf age, and that of calcium, magnesium, iron, manganese, and zinc increased with leaf age. These findings indicate the relative leaf age and the amount of shade or incident light at the leaf level must be recorded and reported for leaf tissue studies in cycads in order to reduce ambiguity and ensure repeatability.
\end{abstract}

Keywords: cycad; essential elements; plant nutrients; stoichiometry; tissue sampling

\section{Introduction}

Cycad plants are unique gymnosperms and more focused studies into cycad biology, ecology, and horticulture may inform contemporary research agendas [1,2]. An interest in cycad horticulture and conservation has prompted recent research into leaf nutrient concentrations. We argue that there is a need to standardize sampling protocols and conduct more case studies to fully understand what controls leaf nutrient status of cycad species and to compare these traits with other gymnosperm and angiosperm taxa [3]. The sampling protocols have been diverse and the level of detail in sampling methods contrasts among the reports [4-15]. We have recently shown that plant size [4] and position of leaflet along the rachis [5] are two plant traits that should be recorded to ensure repeatable methods in cycad leaf nutrient studies. Additionally, the nutrient status of the soils within the leaf umbrella of the sampled plants needs to be quantified and reported, as this soil differs in nutrient content from that of the bulk community soil [6].

Two of the plant traits that may influence leaf nutrient concentrations for a range of plants are sun exposure at the leaf level and leaf age. Details on these influential traits are missing from the methods of most published reports on cycad leaf nutrients [7-15]. Our objectives were to evaluate the influence of these two plant traits on variation in leaf nutrients for the arborescent $C y c a s$ micronesica, a species with a native range that includes Palau, Yap, Guam, and Rota Islands [16]. 


\section{Materials and Methods}

\subsection{Incident Light}

A Yap habitat was utilized to determine the influence of shade on C. micronesica leaf nutrients from 12-14 October $2016\left(9^{\circ} 32^{\prime} \mathrm{N}\right)$. The soils were formed in residuum derived from green, chlorite, and talc schist (Clayey-skeletal, mixed, isohyperthermic Lithic Tropudalfs) [17]. The habitat contained more than 1200 trees per ha, and we used this high density to locate seven pairs of trees to compare sun versus shade. We ensured that the height of the two trees in each pair was homogeneous, and the two trees were located less than $20 \mathrm{~m}$ apart to minimize soil heterogeneity. The level of midday incident light was quantified with a $0.75 \mathrm{~m}$ line quantum sensor (EMS-7, PP Systems, Amesbury, MA, USA), and we only selected shaded plants with $25 \%$ to $30 \%$ sunlight transmission in order to limit the variation among the shaded replications. Leaflet sampling was restricted to 1100-1300 HR for this study to coincide with the incident light measurements. The height of each tree pair was measured, and ranged from $50 \mathrm{~cm}$ to $230 \mathrm{~cm}$.

Each tree was treated as one replication, and we collected leaflets from the youngest flush of leaves, and included leaves growing in the directions north, east, south, and west. From each leaf, we collected leaflets from the base, midpoint, and apex of the rachis. All leaflets for each tree were combined into a single composite sample.

Tissue for nutrient analysis was dried at $75^{\circ} \mathrm{C}$ and milled to pass through a 20-mesh screen. Total nitrogen $(\mathrm{N})$ and carbon $(\mathrm{C})$ were determined by dry combustion (FLASH EA1112 CHN Analyzer, Thermo Fisher, Waltham, MA, USA) [18]. Samples were also digested by a microwave system with nitric acid and peroxide, then phosphorus $(\mathrm{P})$, potassium $(\mathrm{K})$, calcium $(\mathrm{Ca})$, magnesium $(\mathrm{Mg})$, iron $(\mathrm{Fe})$, boron $(\mathrm{B})$, manganese $(\mathrm{Mn})$, zinc $(\mathrm{Zn})$, and copper $(\mathrm{Cu})$ were quantified by inductively coupled plasma optical emission spectroscopy (Spectro Genesis; SPECTRO Analytical Instruments, Kleve, Germany) [19]. We then calculated the $\mathrm{C} / \mathrm{N}, \mathrm{C} / \mathrm{P}, \mathrm{C} / \mathrm{K}, \mathrm{N} / \mathrm{P}, \mathrm{N} / \mathrm{K}$, and $\mathrm{K} / \mathrm{P}$ quotients.

We also collected 10 leaflets from each of the experimental trees to determine the mass-area relationship for sun and shaded trees. From these, 30 leaflets were randomly selected then a section $2-3 \mathrm{~cm}$ in length was cut from the midpoint of each leaflet. The length and diameter of each section was measured, then the area was calculated. The tissue was dried to a constant weight at $75^{\circ} \mathrm{C}$ and dry weight was measured.

\subsection{Leaf Age}

Trees from the Yap habitat were used to determine the influence of leaf age on leaf tissue content of essential elements on 3-5 March 2018. The position of the leaf flush, defined as the distance from the stem apex, was used as the metric of leaf age. The persistent cataphylls that separate each successive leaf flush enable chronological definition of the leaf flushes by proximity to stem apex [4]. We restricted the selection of trees to those with four vegetative flushes consisting of fully green leaves and with no evidence of a recent reproductive event. The need to exclude trees with signs of a recent reproductive event was based on the assumption that the reproductive tissues act as strong resource sinks, and this sink activity may have directly influenced concurrent leaf elemental relations. This approach did not enable an opportunity to identify the sex of each tree. For each leaf flush, we included leaves growing in the directions north, east, south, and west. From each leaf, we collected leaflets from the base, midpoint, and apex of the rachis. All leaflets for each flush were combined into a single composite sample for each replication. Six homogeneous trees were selected within the height range of 2.0 to $2.5 \mathrm{~m}$. Tissue preparation and analysis were as described above.

\subsection{Soils}

A soil sample was collected beneath each sampled tree and combined into a composite sample for each location in accordance with established soil sampling protocols [20]. Total C and $\mathrm{N}$ contents were determined by dry combustion. Extractable essential nutrients other than $\mathrm{P}$ were quantified 
following digestion with diethylenetriaminepentaacetic acid [21], and total metals were quantified following digestion with nitric acid [22]. Analysis was by inductively coupled plasma optical emission spectrometry. Available P was determined by the modified Truog method [23] for the acid Yap soils. The $\mathrm{pH}$ was 5.9 and elemental content was $922.1 \mathrm{mg} \cdot \mathrm{g}^{-1} \mathrm{C}, 5.2 \mathrm{mg} \cdot \mathrm{g}^{-1} \mathrm{~N}, 12.4 \mu \mathrm{g} \cdot \mathrm{g}^{-1} \mathrm{P}, 98.6 \mu \mathrm{g} \cdot \mathrm{g}^{-1} \mathrm{~K}$, $2.0 \mathrm{mg} \cdot \mathrm{g}^{-1} \mathrm{Ca}, 1.4 \mathrm{mg} \cdot \mathrm{g}^{-1} \mathrm{Mg}, 14.1 \mu \mathrm{g} \cdot \mathrm{g}^{-1} \mathrm{Mn}, 318.6 \mu \mathrm{g} \cdot \mathrm{g}^{-1} \mathrm{Fe}, 3.8 \mu \mathrm{g} \cdot \mathrm{g}^{-1} \mathrm{Cu}$, and $7.9 \mu \mathrm{g} \cdot \mathrm{g}^{-1} \mathrm{Zn}$.

\subsection{Statistics}

We attempted to restrict the tree heights for the replications of the shade study to remove the influence of height on leaf traits. We were unable to find seven pairs of trees that met all of our other selection criteria within a limited height range, so we instead employed the use of analysis of covariance (SAS 9.3; SAS Institute, Cary, Indiana) with tree height as the covariate. The influence of shade on leaf traits was not influenced by tree height for any of the response variables for the mass-based or area-based concentrations. Thereafter, we used a paired $t$-test to determine differences between shade and sun leaves for all response variables. The six stoichiometric variables were log-transformed prior to analysis. We used linear and quadratic regression analysis (SAS 9.3) of the essential element concentrations to determine the influence of leaf age as the independent variable, with 1 designated as the youngest flush and 4 designated as the oldest flush.

\section{Results and Discussion}

\subsection{Incident Light}

The level of sun exposure of sampled leaves exerted a strong influence on leaf tissue results. Mass-based concentration of $\mathrm{C}$ was decreased and that of N, P, and $\mathrm{K}$ were increased by shade when compared with sun (Table 1). The remainder of the mass-based element concentrations were not influenced by shade.

Table 1. The influence of light exposure of Cycas micronesica leaves on mass-based leaflet nutrient concentrations for plants growing in schist soils in Yap. Shade leaves received $25 \%$ to $30 \%$ sunlight transmission through a native forest tree canopy. Means $\pm \mathrm{SE}, n=7$.

\begin{tabular}{cccc}
\hline Leaf Trait & Sun & Shade & Significance $^{\mathbf{1}^{\prime}}$ \\
\hline Carbon $\left(\mathrm{mg} \cdot \mathrm{g}^{-1}\right)$ & $492.91 \pm 1.57$ & $484 \pm 1.99$ & 0.0441 \\
Nitrogen $\left(\mathrm{mg} \cdot \mathrm{g}^{-1}\right)$ & $23.42 \pm 0.87$ & $26.79 \pm 0.82$ & 0.0153 \\
Phosphorus $\left(\mathrm{mg} \cdot \mathrm{g}^{-1}\right)$ & $1.76 \pm 0.08$ & $2.47 \pm 0.11$ & 0.0002 \\
Potassium $\left(\mathrm{mg} \cdot \mathrm{g}^{-1}\right)$ & $14.10 \pm 1.01$ & $19.08 \pm 0.93$ & 0.0035 \\
Calcium $\left(\mathrm{mg} \cdot \mathrm{g}^{-1}\right)$ & $1.83 \pm 0.30$ & $1.17 \pm 0.34$ & 0.1687 \\
Magnesium $\left(\mathrm{mg} \cdot \mathrm{g}^{-1}\right)$ & $2.52 \pm 0.24$ & $2.57 \pm 0.19$ & 0.8596 \\
Iron $\left(\mu \mathrm{g} \cdot \mathrm{g}^{-1}\right)$ & $42.86 \pm 1.79$ & $43.57 \pm 2.34$ & 0.8110 \\
Manganese $\left(\mu \mathrm{g} \cdot \mathrm{g}^{-1}\right)$ & $26.14 \pm 2.35$ & $31.0 \pm 2.91$ & 0.2233 \\
Zinc $\left(\mu \mathrm{g} \cdot \mathrm{g}^{-1}\right)$ & $20.43 \pm 2.53$ & $23.71 \pm 3.21$ & 0.4432 \\
Copper $\left(\mu \mathrm{g} \cdot \mathrm{g}^{-1}\right)$ & $3.14 \pm 0.27$ & $3.14 \pm 0.26$ & 1.0000 \\
Boron $\left(\mu \mathrm{g} \cdot \mathrm{g}^{-1}\right)$ & $11.57 \pm 1.29$ & $14.29 \pm 0.75$ & 0.0934 \\
\hline \multicolumn{2}{c}{${ }^{1}$ Paired $t$-test. }
\end{tabular}

The binary relationships among $\mathrm{C}, \mathrm{N}, \mathrm{P}$, and $\mathrm{K}$ were also strongly influenced by incident light level. Sun leaves exhibited C/N, C/P, C/K, and N/P that were greater than those of shade leaves (Table 2). The incident light level did not influence $\mathrm{N} / \mathrm{K}$ or K/P.

The mass to area relationship of leaflets from full sun was $146.3 \mathrm{~g} \cdot \mathrm{m}^{2}$ and that of the leaflets from shade was $83.5 \mathrm{~g} \cdot \mathrm{m}^{2}$. The mass-based nutrient concentration data were converted to area-based concentration using these mass-area relationships. The influence of incident light on area-based leaflet nutrient concentrations was more extensive than the influence on mass-based concentrations. Leaves growing in the sun exhibited greater area-based concentrations of every macronutrient and every micronutrient than leaves growing in the shade (Table 3). 
Table 2. The influence of light exposure of Cycas micronesica leaves on stoichiometry of leaflet nutrients for plants growing in schist soils in Yap. Shade leaves received 25\% to 30\% sunlight transmission through a native forest tree canopy. Means \pm SE, $n=7$.

\begin{tabular}{cccc}
\hline Leaf Trait & Sun & Shade & Significance $^{\mathbf{1}}$ \\
\hline Carbon/nitrogen & $21.21 \pm 0.75$ & $18.17 \pm 0.53$ & 0.0034 \\
Carbon/potassium & $282.39 \pm 12.85$ & $197.90 \pm 8.45$ & $<0.0001$ \\
Carbon/phosphorus & $36.51 \pm 0.66$ & $25.75 \pm 1.34$ & 0.0033 \\
Nitrogen/potassium & $13.38 \pm 0.66$ & $10.95 \pm 0.59$ & 0.0142 \\
Nitrogen/phosphorus & $1.73 \pm 0.16$ & $1.43 \pm 0.09$ & 0.1327 \\
Potassium/phosphorus & $8.00 \pm 0.58$ & $7.75 \pm 0.36$ & 0.8032 \\
\hline
\end{tabular}

${ }^{1}$ Paired $t=$ test on log-transformed data.

Table 3. The influence of light exposure of Cycas micronesica leaves on area-based leaflet nutrient concentrations for plants growing in schist soils in Yap. Shade leaves received $25 \%$ to $30 \%$ sunlight transmission through a native forest tree canopy. Means $\pm \mathrm{SE}, n=7$.

\begin{tabular}{cccc}
\hline Leaf Trait & Sun & Shade & Significance $\mathbf{1}^{\mathbf{1}}$ \\
\hline Carbon $\left(\mathrm{g} \cdot \mathrm{m}^{-2}\right)$ & $72.11 \pm 0.18$ & $40.41 \pm 0.08$ & $<0.0001$ \\
Nitrogen $\left(\mathrm{g} \cdot \mathrm{m}^{-2}\right)$ & $3.43 \pm 0.13$ & $2.24 \pm 0.07$ & $<0.0001$ \\
Phosphorus $\left(\mathrm{g} \cdot \mathrm{m}^{-2}\right)$ & $0.26 \pm 0.01$ & $0.21 \pm 0.01$ & 0.0035 \\
Potassium $\left(\mathrm{g} \cdot \mathrm{m}^{-2}\right)$ & $2.06 \pm 0.15$ & $1.59 \pm 0.07$ & 0.0172 \\
Calcium $\left(\mathrm{g} \cdot \mathrm{m}^{-2}\right)$ & $0.27 \pm 0.04$ & $0.10 \pm 0.03$ & 0.0067 \\
Magnesium $\left(\mathrm{g} \cdot \mathrm{m}^{-2}\right)$ & $0.37 \pm 0.04$ & $0.21 \pm 0.02$ & 0.0020 \\
Iron $\left(\mathrm{mg} \cdot \mathrm{m}^{-2}\right)$ & $6.25 \pm 0.26$ & $3.65 \pm 0.19$ & $<0.0001$ \\
Manganese $\left(\mathrm{mg} \cdot \mathrm{m}^{-2}\right)$ & $3.84 \pm 0.35$ & $2.59 \pm 0.24$ & 0.0132 \\
Zinc $\left(\mathrm{mg} \cdot \mathrm{m}^{-2}\right)$ & $3.00 \pm 0.38$ & $1.97 \pm 0.27$ & 0.0471 \\
Copper $\left(\mathrm{mg} \cdot \mathrm{m}^{-2}\right)$ & $0.44 \pm 0.04$ & $0.27 \pm 0.02$ & 0.0016 \\
Boron $\left(\mathrm{mg} \cdot \mathrm{m}^{-2}\right)$ & $1.69 \pm 0.16$ & $1.19 \pm 0.09$ & 0.0239 \\
\hline
\end{tabular}

${ }^{1}$ Paired $t$-test.

\subsection{Leaf Age}

Cycas micronesica leaf age strongly influenced the macronutrient concentrations. The youngest two leaf flushes were similar in concentration for all nutrients. Nitrogen declined 33\%, P declined 64\%, and $\mathrm{K}$ declined $85 \%$ from the first to the fourth leaf flush (Figure 1). Calcium increased 4.7 -fold and $\mathrm{Mg}$ increased 1.7-fold from the first to the fourth leaf flush. Carbon concentration did not differ among the four leaf flushes. 


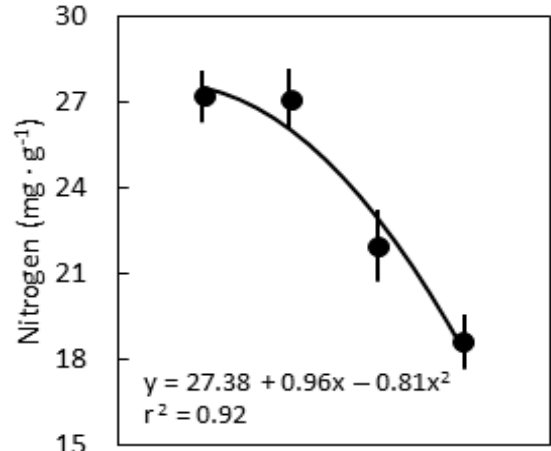

(a)
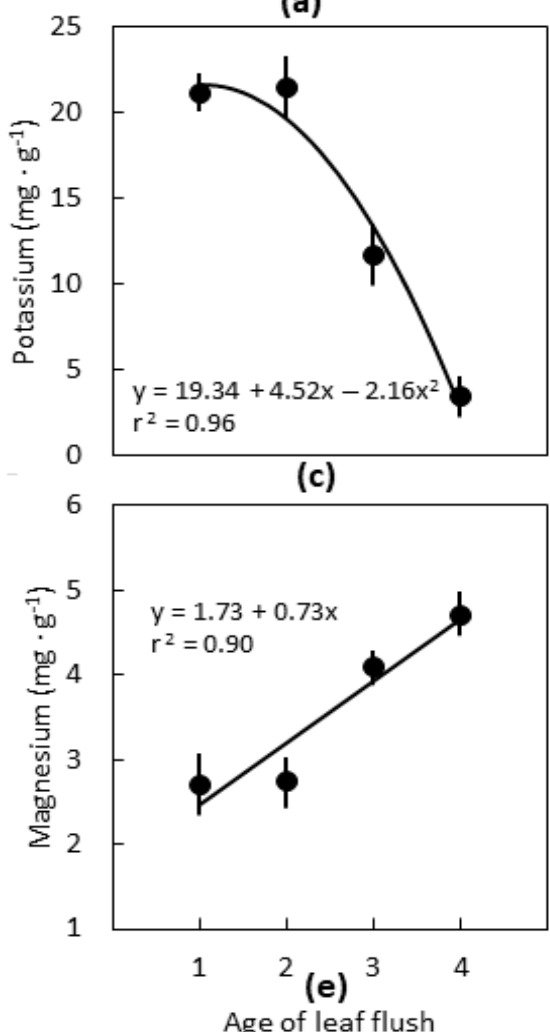

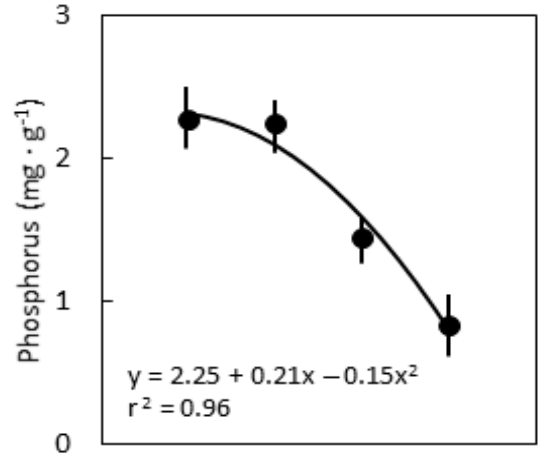

(b)
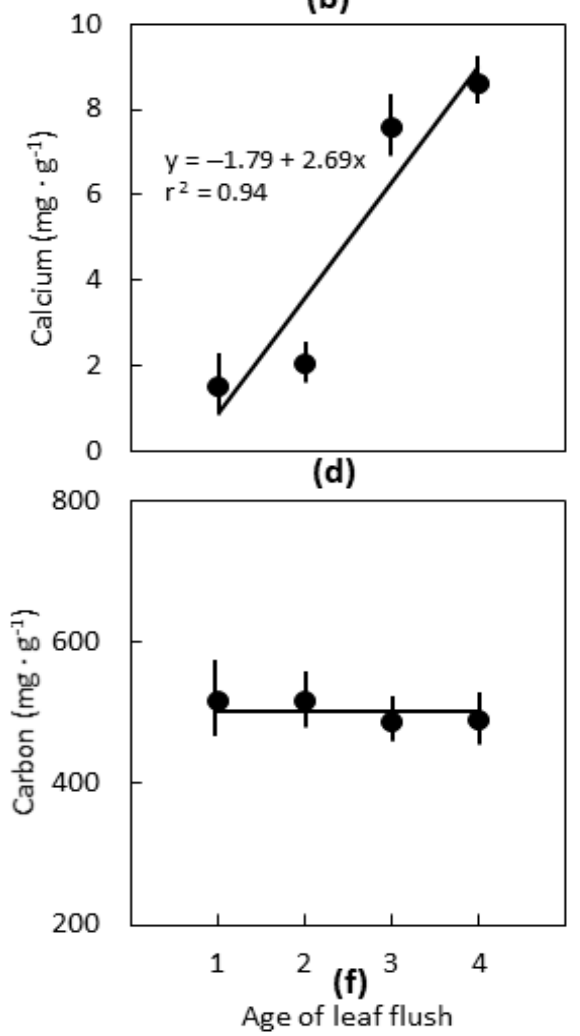

Figure 1. The influence of the position of Cycas micronesica leaves on leaflet macronutrient concentration for plants growing in schist soils in Yap. Flush 1 was the youngest leaf flush, flush 4 was the oldest leaf flush. (a) Nitrogen; (b) phosphorus; (c) potassium; (d) calcium; (e) magnesium; (f) carbon. $n=6$, mean \pm SE.

The micronutrients were influenced by leaf age relatively less than the macronutrients. Iron increased 21\%, Mn increased 62\%, and $\mathrm{Zn}$ increased 100\% from the first to the fourth leaf flush (Figure 2). Boron $\left(\right.$ mean $=14.19 \mu \mathrm{g} \cdot \mathrm{g}^{-1}$ ) and $\mathrm{Cu}\left(\right.$ mean $\left.=2.73 \mu \mathrm{g} \cdot \mathrm{g}^{-1}\right)$ concentrations did not differ among the four leaf flushes. 

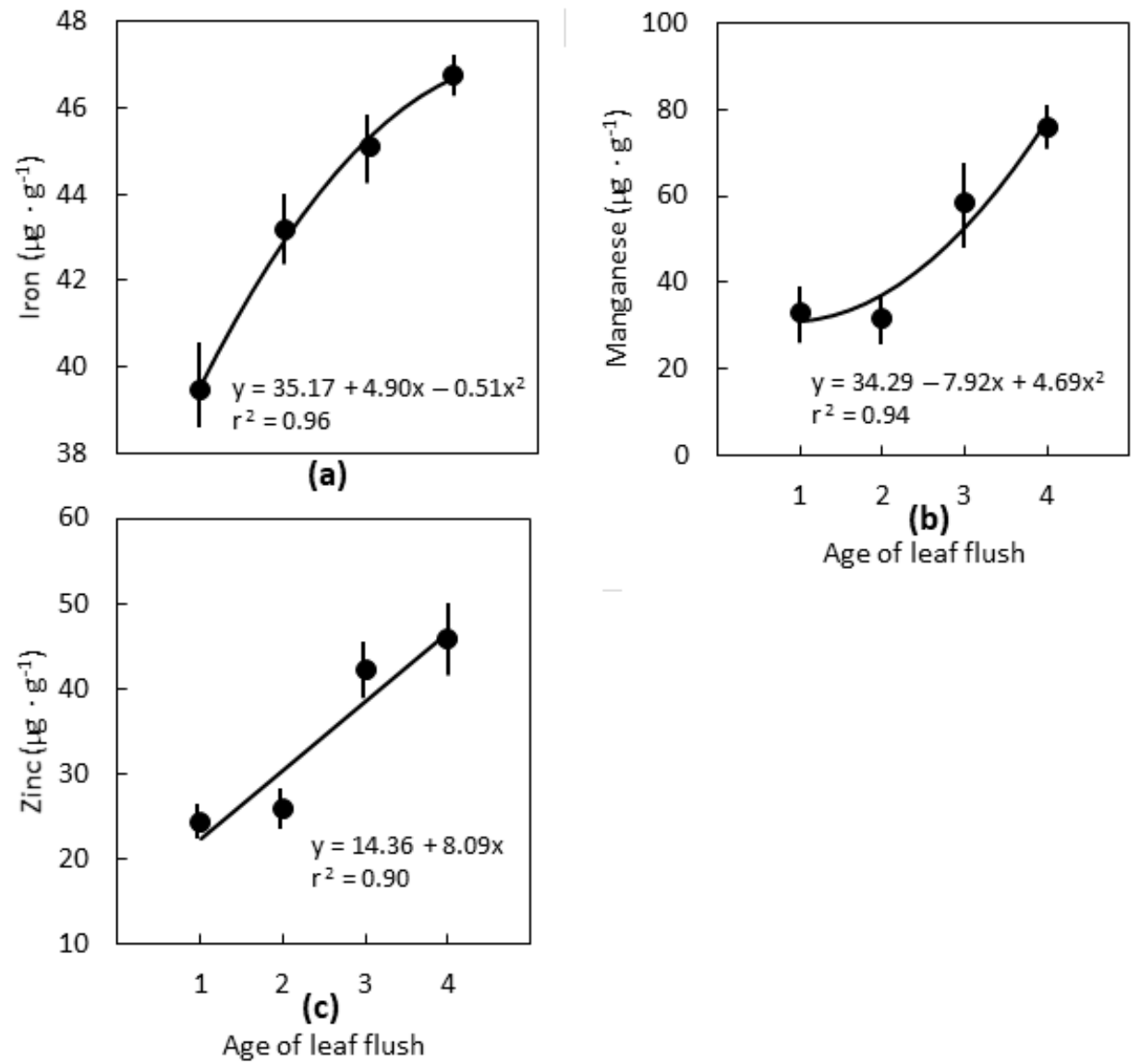

Age of leaf flush

Figure 2. The influence of the position of Cycas micronesica leaves on leaflet micronutrient concentration for plants growing in schist soils in Yap. Flush 1 was the youngest flush, flush 4 was the oldest flush. (a) Iron; (b) manganese; (c) zinc. $n=6$, mean \pm SE.

Leaf age influenced most of the calculated stoichiometric traits. The binary C:N:P:K relationships exhibited non-linear patterns from the first to the fourth leaf flush because the concentrations were similar for the youngest two flushes then changed for the third and fourth flushes. The fourth leaf flush exhibited $\mathrm{C} / \mathrm{N}$ that was 1.4 -fold greater, $\mathrm{C} / \mathrm{P}$ that was 2.9 -fold greater, $\mathrm{C} / \mathrm{K}$ that was 7.3 -fold greater, $\mathrm{N} / \mathrm{P}$ that was 1.9-fold greater, and $\mathrm{N} / \mathrm{K}$ that was 5.5 -fold greater than the first leaf flush (Figure 3). In contrast, $\mathrm{K} / \mathrm{P}$ of the fourth leaf flush was $40 \%$ of that for the first leaf flush. 

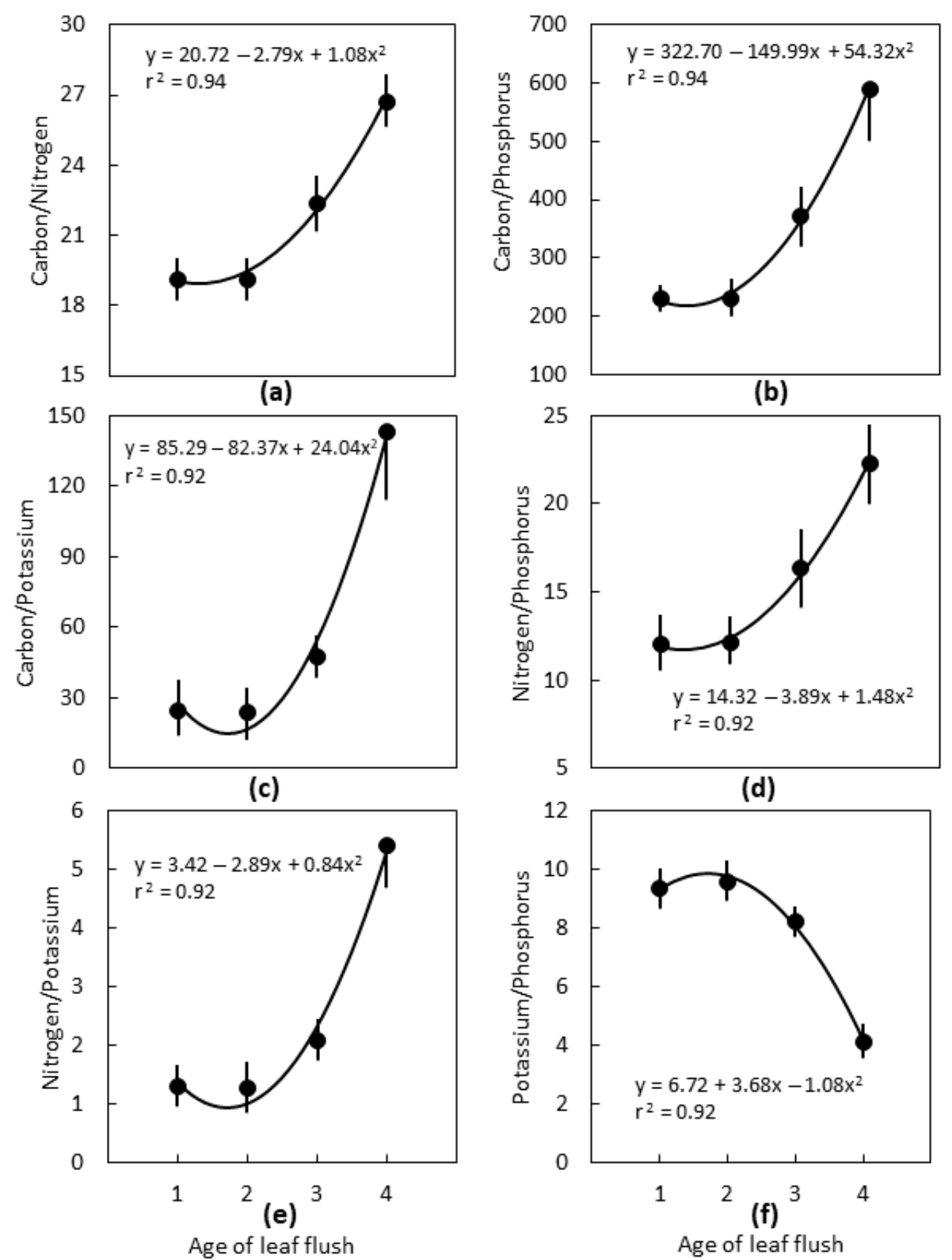

Figure 3. The influence of position of Cycas micronesica leaves on binary C:N:P:K relationships for plants growing in schist soils in Yap. Flush 1 was the youngest flush, flush 4 was the oldest flush. (a) $\mathrm{C} / \mathrm{N}$; (b) $\mathrm{C} / \mathrm{P}$; (c) $\mathrm{C} / \mathrm{K}$; (d) N/P; (e) N/K; (f) K/P. $n=6$, mean $\pm \mathrm{SE}$.

\subsection{Interpretations}

The field methods for sampling soil or plant tissue for the purpose of quantifying plant essential elements are plagued by heterogeneities, and accurate experimental methods require a full knowledge of the factors that directly influence nutrient concentrations. We have shown that Cycas leaf age exerted a profound influence on nutrient concentrations. Therefore, a direct measure of leaf age or the determination of which historical leaf flush a sampled leaf resides within is a mandatory component of the methods for future studies on cycad species. This can be accommodated by sampling every leaf of a plant [24] or by explicating which leaf flush was used for obtaining the samples [4,5]. We have also shown herein that the incident light at the leaf level influenced mass-based nutrient concentrations for many of the essential elements and influenced the area-based nutrient concentrations for all 11 of 
the elements that we measured. For sampled plants growing in full sun, an advised approach is to be sure that only sun-exposed leaves are sampled [13-15,24]. Most in situ cycad habitats and most botanical gardens do not provide full sun conditions for the resident cycad plants. For plants that are not growing in full sun, measuring the amount of incident light $[4,5]$ is a mandatory component of the methods for all future studies. In cultivated conditions where commercial shade fabric is employed, a description of percent shade would be sufficient. Our measured amplitude of variation for some of the elements was extensive, indicating the results reported from cycad tissue analysis studies are equivocal when leaf age and incident light are not reported in the methods.

More cycad species need to be studied to determine if our results apply to this single model species, are restricted in relevance to the subgeneric division Rumphiae [16], apply to the genus Cycas, or apply to most of the 355 described cycads [25]. Until more research is conducted, our results confirm that more specificity in sampling protocols is required for all cycad species. Moreover, all cycad species are dioecious [1]. Preliminary work has shown that some ecophysiology traits may be under the influence of plant sex [9]. We avoided trees with evidence of recent reproductive events to remove the influence of variations in resource allocations due to historical sink activities of reproductive structures. Continued research is needed to determine the influence of tree sex on the manner in which leaf age and incident light influence cycad leaf nutrient concentrations.

\section{Conclusions}

We have used Cycas micronesica trees to show that leaf tissue sampling protocols for cycad research need to include the level of incident light at the leaf level and a description of location of the sampled leaves within the leaf crown as an estimate of leaf age. Based on past studies, the relative size of the plant [4], the location of sampled leaflets along the rachis [5], and the available nutrients in the soils underneath the leaf umbrella of the sampled plant [6] are also mandatory components of sampling methods for cycad tissue analysis results to be valid. Adherence to these required components of the methods will improve the comparisons among the various species and research groups that are involved in reporting future cycad tissue analysis data and will more accurately position cycads within the global database. Future assessments of cycad plant nutrient status will require adherence to these detailed tissue sampling methods.

Author Contributions: Conceptualization, T.E.M.; methodology, T.E.M.; software, T.E.M.; formal analysis, T.E.M.; investigation, T.E.M. and M.V.K.; resources, T.E.M. and M.V.K.; data curation, T.E.M.; writing-original draft preparation, T.E.M.; writing-review and editing, M.V.K.; project administration, T.E.M.; funding acquisition, T.E.M.

Funding: This research was funded by United States Forest Service grant number 13-DG-11052021-210 and 17- DG-11052021-217.

Acknowledgments: We thank the College of Micronesia land grant program for their support.

Conflicts of Interest: The authors declare no conflict of interest.

\section{References}

1. Norstog, K.J.; Nicholls, T.J. The Biology of the Cycads; Cornell University Press: Ithaca, NY, USA, 1997; ISBN 978-0-8014-3033-6.

2. Brenner, E.D.; Stevenson, D.W.; Twigg, R.W. Cycads: Evolutionary innovations and the role of plant-derived neurotoxins. Trends Plant. Sci. 2003, 8, 446-452. [CrossRef]

3. Marler, T.E.; Lindström, A.J. Inserting cycads into global nutrient relations data sets. Plant. Signal. Behav. 2018, 13, e1547578. [CrossRef] [PubMed]

4. Marler, T.E.; Krishnapillai, M.V. Does plant size influence leaf elements in an arborescent cycad. Biology 2018, 7, 51. [CrossRef] [PubMed]

5. Marler, T.E.; Krishnapillai, M.V. Distribution of elements along the rachis of Cycas micronesica leaves: A cautionary note for sampling design. Horticulturae 2019, 5, 33. [CrossRef]

6. Marler, T.E.; Krishnapillai, M.V. Cycas micronesica trees alter local soil traits. Forests 2018, 9, 565. [CrossRef] 
7. Álvarez-Yépiz, J.C.; Cueva, A.; Dovčiak, M.; Teece, M.; Yepez, E.A. Ontogenetic resource-use strategies in a rare long-lived cycad along environmental gradients. Conserv. Physiol. 2014, 2. [CrossRef] [PubMed]

8. Grove, T.S.; O'Connell, A.M.; Malajczuk, N. Effects of fire on the growth, nutrient content and rate of nitrogen fixation of the cycad Macrozamia riedlei. Austral. J. Bot. 1980, 28, 271-281. [CrossRef]

9. Krieg, C.; Watkins, J.E.; Chambers, S.; Husby, C.E. Sex-specific differences in functional traits and resource acquisition in five cycad species. AoB PLANTS 2017, 9, plx013. [CrossRef] [PubMed]

10. Marler, T.E.; Ferreras, U.F. Disruption of leaf nutrient remobilization in coastal Cycas trees by tropical cyclone damage. J. Geogr. Nat. Disast. 2015, 5, 142. [CrossRef]

11. Marler, T.E.; Ferreras, U.F. Current status, threats and conservation needs of the endemic Cycas wadei Merrill. J. Biodivers. Endanger. Species 2017, 5, 193. [CrossRef]

12. Watanabe, T.; Broadley, M.R.; Jansen, S.; White, P.J.; Takada, J.; Satake, K.; Takamatsu, T.; Tuah, S.J.; Osaki, M. Evolutionary control of leaf element composition in plants. New Phytol. 2007, 174, 516-523. [CrossRef] [PubMed]

13. Zhang, Y.; Cao, K.; Sack, L.; Li, N.; Wei, X.; Goldstein, G. Extending the generality of leaf economic design principles in the cycads, an ancient lineage. New Phytol. 2015, 206, 817-829. [CrossRef] [PubMed]

14. Zhang, Y.J.; Sack, L.; Cao, K.-F.; Wei, X.-W.; Li., N. Speed versus endurance tradeoff in plants: Leaves with higher photosynthetic rates show stronger seasonal declines. Sci. Rep. 2017, 7, 42085. [CrossRef] [PubMed]

15. Zhang, Y.-J.; Sack, L.; Goldstein, G.; Cao, K.-F. Hydraulic determination of leaf nutrient concentrations in cycads. Mem. NY Bot. Gard. 2018, 117, 179-192.

16. Hill, K.D. The Cycas rumphii complex (Cycadaceae) in New Guinea and the Western Pacific. Aust. Syst. Bot. 1994, 7, 543-567. [CrossRef]

17. Smith, C.W. Soil Survey of Islands of Yap Federated States of Micronesia; U.S. Dept. of Agric. Soil Conservation Service: Washington, DC, USA, 1983.

18. Dumas, J.B.A. Procedes de L'analyse Organique. Ann. Chim. Phys. 1831, 47, 198-205.

19. Hou, X.; Jones, B.T. Inductively coupled plasma/optical emission spectrometry. In Encyclopedia of Analytical Chemistry; Meyers, R.A., Ed.; John Wiley \& Sons: Chichester, UK, 2000; pp. 9468-9485.

20. Carter, M.R.; Gregorich, E.G. (Eds.) Soil Sampling and Methods of Analysis, 2nd ed.; CRC Press: Boca Raton, FL, USA, 2008; ISBN 978-0-8493-3586-0.

21. Berghage, R.D.; Krauskopf, D.M.; Warncke, D.D.; Widders, I. Micronutrient testing of plant growth media extractant, identification and evaluation. Commun. Soil Sci. Plant. Anal. 1987, 18, 1089-1109. [CrossRef]

22. Zheljazkov, V.D.; Warman, P.R. Comparison of three digestion methods for the recovery of 17 plant essential nutrients and trace elements from six composts. Compost Sci. Utiliz. 2002, 10, 197-203. [CrossRef]

23. Hue, N.V.; Ikawa, H.; Huang, X. Predicting soil phosphorus requirements. In Plant Nutrient Management in Hawaii's Soils, Approaches for Tropical and Subtropical Agriculture; Silva, J.A., Uchida, R., Eds.; College of Tropical Agriculture and Human Resources, University of Hawaii: Manoa, HI, USA, 2000; pp. 95-99.

24. Marler, T.E. Elemental profiles in Cycas micronesica stems. Plants 2018, 7, 94. [CrossRef] [PubMed]

25. Calonje, M.; Stevenson, D.W.; Osborne, R. The World List of Cycads, online edition. 2013-2019. Available online: http://www.cycadlist.org (accessed on 26 July 2019).

(C) 2019 by the authors. Licensee MDPI, Basel, Switzerland. This article is an open access article distributed under the terms and conditions of the Creative Commons Attribution (CC BY) license (http://creativecommons.org/licenses/by/4.0/). 